\title{
Dibutyl Phthalate (DBP)-Induced Apoptosis and Neurotoxicity are Mediated via the Aryl Hydrocarbon Receptor (AhR) but not by Estrogen Receptor Alpha (ER $\alpha)$, Estrogen Receptor Beta (ERß), or Peroxisome Proliferator-Activated Receptor Gamma (PPAR $\gamma$ ) in Mouse Cortical Neurons
}

\author{
Anna K. Wójtowicz ${ }^{1} \cdot$ Konrad A. Szychowski ${ }^{2}$ Agnieszka Wnuk ${ }^{3}$ • \\ Małgorzata Kajta ${ }^{3}$ \\ Received: 9 July 2016/Revised: 11 August 2016/Accepted: 20 August 2016/Published online: 31 August 2016 \\ (c) The Author(s) 2016. This article is published with open access at Springerlink.com
}

\begin{abstract}
Dibutyl phthalate (di- $n$-butyl phthalate, DBP) is one of the most commonly used phthalate esters. DBP is widely used as a plasticizer in a variety of household industries and consumer products. Because phthalates are not chemically bound to products, they can easily leak out to enter the environment. DBP can pass through the placental and blood-brain barriers due to its chemical structure, but little is known about its mechanism of action in neuronal cells. This study demonstrated the toxic and apoptotic effects of DBP in mouse neocortical neurons in primary cultures. DBP stimulated caspase-3 and LDH activities as well as ROS formation in a concentration $(10 \mathrm{nM}-100 \mu \mathrm{M})$ and time-dependent (3-48 h) manner. DBP induced ROS formation at nanomolar concentrations, while it activated caspase- 3 and LDH activities at micromolar concentrations. The biochemical effects of DBP were accompanied by decreased cell viability and induction of apoptotic bodies. Exposure to DBP reduced $E r \alpha$ and Ppary mRNA expression levels, which were inversely correlated with protein expression of the receptors. Treatment with DBP enhanced $A h r$ mRNA expression, which was reflected by the increased AhR protein level observed
\end{abstract}

Anna K. Wójtowicz

anna.wojtowicz@ur.krakow.pl

1 Department of Animal Biotechnology, Animal Sciences Faculty, University of Agriculture, Redzina 1B,

30-248 Kraków, Poland

2 Department of Public Health, Dietetics and Lifestyle Disorders, Faculty of Medicine, University of Information Technology and Management in Rzeszow, Sucharskiego 2, 35-225 Rzeszow, Poland

3 Department of Experimental Neuroendocrinology, Institute of Pharmacology, Polish Academy of Sciences, Smetna 12, 31-343 Kraków, Poland at $3 \mathrm{~h}$ after exposure. $\mathrm{ER} \alpha, \mathrm{ER} \beta$, and PPAR $\gamma$ antagonists stimulated DBP-induced caspase- 3 and LDH activities. AhR silencing demonstrated that DBP-induced apoptosis and neurotoxicity are mediated by AhR, which is consistent with the results from DBP-induced enhancement of AhR mRNA and protein expression. Our study showed that AhR is involved in DBP-induced apoptosis and neurotoxicity, while the ERs and PPAR $\gamma$ signaling pathways are impaired by the phthalate.

Keywords DBP $\cdot$ Apoptosis $\cdot \mathrm{ER} \alpha \cdot \mathrm{ER} \beta \cdot \mathrm{PPAR} \gamma \cdot \mathrm{AhR}$. Phthalate $\cdot$ Neuron

$\begin{array}{ll}\text { Abbreviations } \\ \text { AhR } & \text { Aryl hydrocarbon receptor } \\ \text { DBP } & \text { Dibutyl phthalate } \\ \text { DMSO } & \text { Dimethyl sulfoxide } \\ \text { ER } \alpha & \text { Estrogen receptor alpha } \\ \text { ER } \beta & \text { Estrogen receptor beta } \\ \text { FBS } & \text { Fetal bovine serum } \\ \mathrm{H}_{2} \text { DCFDA } & 2,7^{\prime} \text {-Dichlorodihydrofluorescein diacetate } \\ \text { LDH } & \text { Lactate dehydrogenase } \\ \text { MPP } & 1,3 \text {-Bis(4-hydroxyphenyl)-4-methyl-5-[4-(2- } \\ & \text { piperidinylethoxy)phenol]-1h-pyrazole } \\ & \text { dihydrochloride } \\ \text { PBS } & \text { Phosphate buffered saline } \\ \text { PHTPP } & \text { 4-[2-Phenyl-5,7- } \\ & \text { bis(trifluoromethyl)pyrazolo[1,5- } \\ & \text { a]pyrimidin-3-yl]phenol } \\ \text { PPAR } \gamma & \text { Peroxisome proliferator-activated receptor } \\ & \text { gamma } \\ \text { ROS } & \text { Reactive oxygen species } \\ \alpha N F & \alpha-N a p h t h o f l a v o n e \\ \beta N F & \beta-N a p h t h o f l a v o n e\end{array}$




\section{Introduction}

Dibutyl phthalate (di- $n$-butyl phthalate, DBP) is one of the most commonly used phthalate esters and is an endocrinedisrupting chemical (EDC). DBP is widely used as plasticizer in a variety of household industries and consumer products, such as toys, food containers, furniture, cosmetics and personal care products, latex adhesives, cellulose plastics, varnishers, and dye solvents (Stales et al. 1997; Shea 2003; Duty et al. 2005; Heudorf et al. 2007). Because phthalates are not chemically bound to products, they can easily diffuse within the materials and enter the environment (Fromme et al. 2002; Fujii et al. 2003). Several studies have evaluated the DBP concentrations in the air and dust of residences and found that DBP could reach detrimentally high levels (Rudel et al. 2003; Adibi et al. 2003; Fromme et al. 2004; Otake et al. 2004). Phthalates are rapidly absorbed after inhalation or oral administration due to their lipophilic properties (Rudel et al. 2003; Adibi et al. 2003; Kavlock et al. 2006). DBP has been found in various tissues, despite the fact that it is rapidly hydrolyzed to monobutyl phthalate by non-specific lipases and esterases (Rowland et al. 1977; Tanaka et al. 1978; Foster et al. 1983). Elevated DBP concentrations have been found in human cord blood $(68.14 \mu \mathrm{g} / \mathrm{L}=244.8 \mathrm{nM})$, milk (42 ng/ $\mathrm{mL}=150.89 \mathrm{nM})$, blood $(9.1 \mathrm{ng} / \mathrm{mL}=32.69 \mathrm{nM})$, and urine (38 ng/mL = $136.52 \mathrm{nM}$ ) (Högberg et al. 2008; Huang et al. 2014). A study conducted on male Wistar rats showed that DBP was detected in rat brains after a single oral dose (Williams and Blanchfield 1975). Furthermore, DBP accumulation was much higher after chronic (3 or 6 months) exposure than after a single inhalation (Kawano 1980), thus indicating effective accumulation of the phthalate in brain tissue. DBP has also been shown to pass through the placental and blood-brain barriers in rats (Williams and Blanchfield 1975; Kawano 1980; Saillenfait et al. 1998; Huang et al. 2014). However, little is known about mechanisms of action of DBP in the nervous system, especially in the early developmental stages.

A recent report showed that DBP caused deleterious effects in the developing nervous system. This compound inhibited acetylcholinesterase activity in zebrafish (Danio rerio) embryos and up-regulated transcripts of growth-associated protein 43, embryonic lethal abnormal vision-like 3 , glial fibrillary acidic protein, myelin basic protein, $\alpha 1-$ tubulin and neurogenin1 (Xu et al. 2013). DBP also had adverse effects on the behavior and cognitive abilities of rats that were prenatally exposed to the phthalate (Li et al. 2009). Recently, exposures to DBP have been correlated with behavioral disorders in eight-year-old children (Lien et al. 2014). Moreover, Li et al. (2013, 2014) found altered expression of aromatase, estrogen beta receptor (ER $\beta)$, brain-derived neurotrophic factor, and p-CREB as well as cytotoxicity and apoptosis in the hippocampal neurons of DBP-exposed immature rats. Extensive reactive oxygen species (ROS) production and oxidative DNA damage were detected in rat livers, kidneys, and testes following exposure of rats to DBP (Wellejus et al. 2002). Oxidative stress was recently shown to have a critical role in DBPinduced neurotoxicity in Caenorhabditis elegans (Tseng et al. 2013). DBP is capable of binding to nuclear receptors, such as estrogen receptor alpha $(\mathrm{ER} \alpha)$, ER $\beta$, peroxisome proliferator-activated receptor gamma (PPAR $\gamma$ ), and aryl hydrocarbon receptor (AhR), in various tissues. However, there is almost no data on the involvement of these receptors in the DBP-mediated effects in neural tissues. Although apoptotic and neurotoxic effects of DBP have been identified, its function as an EDC has only been partially characterized. Studies on the involvement of ERs and xenobiotic receptors in DBP-mediated effects are needed.

The aim of the present study was to investigate the cytotoxic and apoptotic effects of DBP and its influence on ROS production in mouse neocortical neurons 3-48 h after exposure. To explore the molecular mechanisms of DBP action on neocortical neurons, we studied the involvement of ER $\alpha, E R \beta, \operatorname{PPAR} \gamma$, and AhR in DBP-induced effects.

\section{Materials and Methods}

\section{Reagents}

Neurobasal medium without phenol red and B27-AO supplements, and the TaqMan probes corresponding to specific genes encoding $\beta$-actin (Mm00607939_s1), AhR (Mm01291777_m1), Esr1 (Mm00433147_m1), Esr2 (Mm01281854_m1), and PPAR $\gamma\left(\mathrm{Mm00440945 \_ m1)} \mathrm{were}\right.$ purchased from Life Technologies (Grand Island, NY, USA). Estradiol (ER agonist), $\alpha$-naphthoflavone ( $\alpha \mathrm{NF}$, AhR antagonist), $\beta$-naphthoflavone ( $\beta N F$, AhR agonist), GW1929 (PPAR $\gamma$ agonist), GW9662 (PPAR $\gamma$ antagonist), trypsin, charcoal/dextran-treated fetal bovine serum (FBS), penicillin, streptomycin, glycerol, Tris, HEPES, CHAPS, DTT, Nonidet NP-40, SDS, EDTA, Tween 20, 2,7'dichlorodihydrofluorescein diacetate $\left(\mathrm{H}_{2} \mathrm{DCFDA}\right)$, bromophenol blue, staurosporine, Hoechst 33342, calcein AM, anti- $\beta$-actin antibody (A5316), DMSO, and DBP (524980) were purchased from Sigma-Aldrich (St. Louis, MO, USA). Caspase-3 substrate was purchased from Merck (Darmstadt, Germany). An ER $\alpha$ antagonist, 1,3-bis(4-hydroxyphenyl)-4methyl-5-[4-(2-piperidinylethoxy)phenol]-1h-pyrazole dihydrochloride (MPP), and an ER $\beta$ antagonist, 4-[2-phenyl-5, 7-bis(trifluoromethyl)pyrazolo[1,5-a]pyrimidin-3-yl]phenol (PHTPP), were purchased from Tocris Bioscience (Bristol, 
United Kingdom). The cytotoxicity detection kit was purchased from Roche Applied Science (Munich, Germany). INTERFERin $^{\circledR}$ siRNA transfection reagent was purchased from Polyplus-transfection (Illkirch, France). AhR siRNA (sc-29655), ER $\alpha$ siRNA (sc-29306), ER $\beta$ siRNA (sc35326), PPAR $\gamma$ siRNA (sc-29456), and anti-AhR (sc8088), anti-ER $\alpha$ (sc-7207), anti-ER $\beta$ (sc-8974), and antiPPAR $\gamma$ (sc-7273) antibodies were purchased from Santa Cruz Biotechnology, Inc. (Santa Cruz, CA, USA). The BioRad protein assay was purchased from Bio-Rad Laboratories (Munich, Germany). Stock solutions of the test compounds were prepared in DMSO and were added to the neurobasal medium. The final concentration of DMSO in the culture medium was always $0.1 \%$.

\section{Primary Cultures of Neocortical Neurons}

The experiments were performed using primary cultures of mouse cortical neurons. These cultures were prepared from the fetuses of pregnant female Swiss mice as previously described (Brewer 1997; Szychowski et al. 2015). Brain tissues were collected from the mouse embryos on day 15 and 16 of gestation. Pregnant females were anesthetized with $\mathrm{CO}_{2}$ vapor and killed by cervical dislocation. The animal care protocols were in accordance with official governmental guidelines, and all efforts were made to minimize the number of animals used and their suffering. All procedures were performed in accordance with the National Institutes of Health Guidelines for the Care and Use of Laboratory Animals and were approved by the Bioethics Commission (No. 83/2012), in compliance with Polish law. The brains were removed from the fetuses, and the cortical tissues were dissected. The dissected tissue was minced into small pieces and then gently digested with trypsin. Then, the cells were centrifuged, and the pellet was resuspended in phenol red-free neurobasal medium supplemented with $5 \%$ charcoal/dextran-treated fetal bovine serum. The cells were plated onto poly-L-ornithine-coated $(0.01 \mathrm{mg} / \mathrm{mL})$ multi-well plates. After 2 days, the culture medium was changed to neurobasal medium supplemented with B27-AO $(2 \mu \mathrm{L} / \mathrm{mL})$, glutamine $(2 \mathrm{mM}), 50 \mathrm{U} / \mathrm{mL}$ penicillin, and $0.05 \mathrm{mg} / \mathrm{mL}$ streptomycin, which is recommended for primary neuronal cultures (Brewer 1997; Kajta et al. 2005). For the experiments, the cells were cultured at a density of $1.8 \times 10^{5} \mathrm{cells} / \mathrm{cm}^{2}$. This procedure typically yields cultures that contain approximately $90 \%$ neurons and $10 \%$ astrocytes (Kajta et al. 2004). The cultures were maintained at $37{ }^{\circ} \mathrm{C}$ in a humidified atmosphere containing $5 \% \mathrm{CO}_{2}$ and were cultivated for 7 days in vitro prior to the experiment. The culture medium was changed prior to treating the cultures with the compounds selected for this study. Experimental concentrations were chosen according to the literature data. The concentrations used by other authors were in a range between $0.61 \mu \mathrm{M}$ in SH-SY5Y cells, 1-100 $\mu \mathrm{M}$ in rat neural stem cells, and $200 \mu \mathrm{M}$ in rat explants of cerebellum (Kasuya 1974; KaunYu et al. 2004; Ishido and Suzuki 2014).

\section{siRNA Gene Silencing}

Specific siRNAs targeting ER $\alpha, \operatorname{ER} \beta, \operatorname{PPAR} \gamma$, and AhR were used to inhibit gene expression in mouse neocortical neurons using a previously described method with modifications (Kajta et al. 2014). The siRNA was applied for $7 \mathrm{~h}$ at a final concentration of $50 \mathrm{nM}$ in antibiotic-free medium containing the siRNA transfection reagent interferin. After transfection, the culture media were changed, and the neurons were cultured for $24 \mathrm{~h}$ before starting the experiment. Controls included positive siRNA and negative siRNA containing a scrambled sequence that did not lead to the specific degradation of any known cellular mRNA. The effectiveness of mRNA silencing was verified by measurement of specific mRNAs with real-time PCR and Western blot analysis and by selective ligand binding to the receptor (results not shown).

\section{Measurement of ROS}

The fluorogenic dye $2,7^{\prime}$-dichlorodihydrofluorescein diacetate $\left(\mathrm{H}_{2} \mathrm{DCFDA}\right)$ was used to detect intracellular ROS. After diffusion into the cell, $\mathrm{H}_{2}$ DCFDA is deacetylated by cellular esterases into a non-fluorescent compound that is subsequently oxidized by ROS into 2,7'-dichlorofluorescein (DCF) (Gomes et al. 2005). ROS levels were measured with $5 \mu \mathrm{M} \mathrm{H}_{2}$ DCFDA to determine the ability of DBP to induce ROS production in the neocortical neurons. For the ROS measurements, the cells were plated onto black-sided, clear-bottomed 96-well plates and exposed to $10 \mathrm{nM}$ to $100 \mu \mathrm{M}$ of DBP for 3,6 , and $24 \mathrm{~h}$. The cells were incubated with $\mathrm{H}_{2}$ DCFDA in serum-free and phenol red-free neurobasal medium for $45 \mathrm{~min}$ before DBP treatment. After 3, 6, and $24 \mathrm{~h}$ of incubation of the cells with $\operatorname{DBP}\left(5 \% \mathrm{CO}_{2}\right.$ at $\left.37{ }^{\circ} \mathrm{C}\right)$, the culture medium was replaced with fresh neurobasal medium to remove extracellular residual DCF and DBP to reduce the fluorescence background. Cells treated with $55 \mu \mathrm{M}$ tert-butyl hydrogen peroxide were used as a positive control (results not shown). The interaction between DBP and $\mathrm{H}_{2}$ DCFDA was tested in cell-free conditions before the experiments (results not shown) to address the concerns about the $\mathrm{H}_{2}$ DCFDA assay previously described by Szychowski and Wójtowicz (2016). DCF fluorescence was detected using a microplate reader (Bio-Tek FLx800) at maximum excitation and emission spectra of 485 and $535 \mathrm{~nm}$, respectively. The data were analyzed using KCJunior software (Bio-Tek Instruments) and were normalized to the fluorescence in 
the vehicle-treated cells. The results are expressed as the mean percent of the control from eight separate samples \pm SEM, and the samples were tested in quadruplicate.

\section{LDH Cytotoxicity Assay}

The cytotoxicity detection kit is a colorimetric assay for the quantification of cell death and cell lysis based on the release of lactate dehydrogenase (LDH) from the cytosol of damaged cells into the supernatant (Koh and Choi 1987). An increase in the amount of dead or plasma membranedamaged cells results in an increase in LDH release in the culture supernatant. Primary neocortical cell cultures were exposed to increasing concentrations $(10,50,100 \mathrm{nM}$ and $10,25,50,100 \mu \mathrm{M})$ of DBP. After the cells were cultured in 96-well plates, $100 \mu \mathrm{L}$ of the medium was collected for the LDH analysis, and the cells were collected and frozen at $-80{ }^{\circ} \mathrm{C}$ for measurement of the caspase-3 activity. Control (no vehicle) and DMSO-treated samples were included in the experimental design to determine the effects of DMSO (results not shown). For the LDH assay, $100 \mu \mathrm{L}$ of the collected supernatant was incubated with the reaction mixture provided in the LDH assay kits. After $30 \mathrm{~min}$, the reaction was stopped by adding $1 \mathrm{~N} \mathrm{HCl}$, and the absorbance was measured at a wavelength of $490 \mathrm{~nm}$ with a reference wavelength of $600 \mathrm{~nm}$ in a micro-ELISA plate reader. The data were analyzed using KCJunior software (Bio-Tek Instruments) and were normalized to the fluorescence in the vehicle-treated cells. The results are expressed as the mean percent of the control from eight separate samples \pm SEM, and the samples were assayed in quadruplicate.

\section{Measurement of Caspase-3 Activity}

Caspase-3 activity was used as a marker for cell apoptosis and was determined using the method described by Nicholson et al. (1995). After thawing $\left(-80{ }^{\circ} \mathrm{C}\right)$, neurons were lysed using lysis buffer (50 mM HEPES, pH 7.4, $100 \mathrm{mM} \mathrm{NaCl}, 0.1 \%$ CHAPS, $1 \mathrm{mM}$ EDTA, $10 \%$ glycerol, $10 \mathrm{mM}$ DTT). The lysates were incubated with the specific substrate for caspase-3, Ac-DEVD-pNA, at $37{ }^{\circ} \mathrm{C}$. Cells treated with $1 \mu \mathrm{M}$ staurosporine were used as a positive control (results not shown). After $30 \mathrm{~min}$, the absorbance of the lysates was measured at $405 \mathrm{~nm}$ in a microplate reader (Bio-Tek ELx800). The formation of the colorimetric product was continuously monitored for $120 \mathrm{~min}$. The data were analyzed using KCJunior (Bio-Tek Instruments) and normalized to the absorbance of the vehicle-treated cells. The results are expressed as the mean percent of the control from eight separate samples \pm SEM, and the samples were assayed in quadruplicate.

\section{Calcein AM Staining}

The esterase activities of living cells are visualized by calcein AM as green fluorescence. Therefore, this staining protocol was used to assess the metabolism and cell viability (Kajta et al. 2009). For calcein AM staining, neurons were seeded on polyornithine-coated coverslips in 24-well plates and cultured in the presence of $10 \mu \mathrm{M}$ of DBP for $24 \mathrm{~h}$. The cells were washed with PBS to eliminate the esterase activity present in the growth media,. The cells grown on glass cover slips were then incubated in $4 \mu \mathrm{M}$ calcein AM in PBS at $37{ }^{\circ} \mathrm{C}$ in a $5 \% \mathrm{CO}_{2}$ atmosphere for $10 \mathrm{~min}$. Cells with bright yellow cytoplasm were identified as living cells. Fluorescence microscopy (Nikon, Japan) was used to visualize the stained cells.

\section{Identification of Apoptotic Cells with Hoechst 33342 Staining}

Apoptotic cells show nuclear condensation and DNA fragmentation, which are detected by Hoechst 33342 staining. Hoechst 33342 binds the DNA fragments and the apoptotic bodies, emitting blue fluorescence (Kajta et al. 2009). For Hoechst 33342 staining, neurons were seeded on polyornithine-coated coverslips in 24-well plates. After an initial treatment with $10 \mu \mathrm{M}$ of DBP for $24 \mathrm{~h}$, the cells were washed with PBS and incubated with Hoechst 33342. Hoechst 33342 was diluted with PBS and added to the medium at a final concentration of $10 \mu \mathrm{M}$. The cells were incubated for $10 \mathrm{~min}$ in a $5 \% \mathrm{CO}_{2}$ atmosphere at $37^{\circ} \mathrm{C}$ and then visualized with a fluorescence microscope (Nikon, Japan).

\section{Western Blot Analysis}

For the estimation of protein expression, neurons were cultured on polyornithine-coated 6-well plates in the presence of $10 \mu \mathrm{M}$ of DBP for different time intervals $(0$, $1,3,6,24$, and $48 \mathrm{~h})$. The cells were lysed in $100 \mu \mathrm{L}$ of ice-cold lysis buffer containing $100 \mathrm{mM} \mathrm{NaCl}, 50 \mathrm{mM}$ Tris $\mathrm{HCl}(\mathrm{pH} 7.5), 0.5 \%$ Na-deoxycholate, $0.5 \%$ Nonidet NP-40, and $0.5 \%$ SDS. Then, the lysates were sonicated and clarified by centrifugation at $15,000 \times g$ at $4{ }^{\circ} \mathrm{C}$ for $20 \mathrm{~min}$, and the supernatant was collected and stored at $-80{ }^{\circ} \mathrm{C}$ until analysis. The protein concentrations in the supernatants were determined with the Bradford method (Bradford 1976) using bovine serum albumin as the standard. From the whole cell lysates, $35 \mu \mathrm{g}$ of total protein was added to an appropriate amount of sample buffer consisting of $125 \mathrm{mM}$ Tris (pH 6.8), $4 \%$ SDS, $25 \%$ glycerol, $4 \mathrm{mM}$ EDTA, $20 \mathrm{mM}$ DTT, and $0.01 \%$ bromophenol blue. Samples were separated by $7.5 \%$ SDS- 
polyacrylamide gel electrophoresis in a Bio-Rad MiniProtean II electrophoresis cell, and the proteins were then transferred to nitrocellulose membranes using a Bio-Rad Mini Trans-Blot apparatus. Following the transfer, the membranes were washed, and non-specific binding sites were blocked with $5 \%$ dried milk and $0.2 \%$ Tween 20 in $0.02 \mathrm{M}$ TBS for $2 \mathrm{~h}$. Then, the membranes were incubated overnight with the anti-PPAR $\gamma$, anti-ER $\alpha$, anti-ER $\beta$, and anti-AhR antibodies diluted 1:200 in TBS/Tween at $4{ }^{\circ} \mathrm{C}$. After incubation with the primary antibodies, the membranes were washed with TBS and $0.02 \%$ Tween 20 and incubated for $2 \mathrm{~h}$ with horseradish peroxidase-conjugated secondary antibodies diluted $1: 500$ in TBS/Tween. $\beta$ Actin was used as a loading control with an anti- $\beta$-actin antibody diluted 1:3000 in TBS/Tween (secondary antibody diluted at 1:5000 in TBS/Tween). Signals were detected by chemiluminescence using western blotting luminol reagent and visualized with a Fuji LAS-4000 phosphorimager. The intensities of the immunoreactive bands were quantified by densitometry. Densitometry was performed using ImageJ $1.47 \mathrm{v}$ software (National Institutes of Health, USA).

\section{Real-Time PCR Analysis of PPAR- $\gamma, \mathrm{ER} \alpha, \mathrm{ER} \beta$, and AhR}

Total RNA was extracted from neocortical neurons exposed to $10 \mu \mathrm{M}$ of DBP for 3 or $6 \mathrm{~h}$ using a previously described method (Kajta et al. 2014). A Qiagen RNeasy mini kit was used for extraction according to the manufacturer's protocol. The quantity of RNA was determined spectrophotometrically at 260 and $280 \mathrm{~nm}$ (ND-1000 UVVis; Thermo Fisher NanoDrop, USA). Two-step real-time RT-PCRs were performed. Both the reverse transcription (RT) reaction and the quantitative polymerase chain reaction (qPCR) were conducted using the CFX96 Real-Time System (Bio-Rad, USA). The RT reaction had a final volume of $20 \mu \mathrm{L}$ with $300 \mathrm{ng}$ of RNA (as a cDNA template) using a cDNA reverse transcription kit according to the manufacturer's protocol. Products of the RT reaction were amplified with the TaqMan Gene Expression Master Mix (Life Technologies Applied Biosystems, USA) kit using TaqMan probes as primers for the specific genes encoding $\beta$-actin, ER $\alpha$, ER $\beta$, PPAR $\gamma$, and AhR. Amplification was carried out in a total volume of $20 \mu \mathrm{L}$ containing 1x TaqMan Gene Expression Master Mix and $1 \mu \mathrm{L}$ of RT product used as the PCR template. The standard qPCR reaction was performed as follows: $2 \mathrm{~min}$ at $50{ }^{\circ} \mathrm{C}$ and 10 min at $95{ }^{\circ} \mathrm{C}$ followed by 40 cycles of $15 \mathrm{~s}$ at $95{ }^{\circ} \mathrm{C}$ and $1 \mathrm{~min}$ at $60^{\circ} \mathrm{C}$. The threshold value $(\mathrm{Ct})$ for each sample was determined during the exponential phase, and the $\Delta \Delta \mathrm{Ct}$ method was used for data analysis. $\beta$-actin was used as the reference gene.

\section{Statistical Analysis}

Data are presented as the mean \pm SEM of four independent experiments. Each treatment was repeated eight times $(n=8)$ and assayed in quadruplicate; thus, the total number of replicates was 32 . The average of the quadruplicate samples was used for the statistical calculations. Data were analyzed by one-way analysis of variance followed by Tukey's multiple comparison test. Differences between the control and experimental groups are indicated as follows: $* p<0.05, * * p<0.01, * * * p<0.001$ versus control cells in all experiments, \#\#\# $<0.001$ versus the cells transfected with the negative siRNA (Figs. 6, 7), $\# p<0.05$, \#\#\#p <0.001, cells treated with $10 \mu \mathrm{M}$ of DBP versus the cells treated with $10 \mu \mathrm{M}$ of DBP with co-administration of a receptor antagonist (Fig. 8).

\section{Results}

\section{DBP-Stimulated ROS Production}

Neocortical neuron cultures were treated with DBP concentrations ranging from $10 \mathrm{nM}$ to $100 \mu \mathrm{M}$. After $3 \mathrm{~h}$ of exposure, the ROS production increased by 34-66\% compared with that of the vehicle control. Increased ROS production was also observed after 6 and $24 \mathrm{~h}$ of treatment, with DBP increasing ROS by $22-84 \%$ of that of the control (Fig. 1). The capacity of DBP to stimulate ROS production increased with the duration of exposure. At $3 \mathrm{~h}$ of exposure, only concentrations of $100 \mathrm{nM}$ DBP or higher stimulated ROS formation at $6 \mathrm{~h}$ of exposure, concentrations of $50 \mathrm{nM}$ DBP or higher stimulated ROS formation and at $24 \mathrm{~h}$ of exposure, DBP was already effective at a concentration of $10 \mathrm{nM}$.

\section{DBP-Induced Effects on LDH Release and Cell Viability}

DBP at concentrations of $10 \mu \mathrm{M}$ or higher $(25,50$, $100 \mu \mathrm{M})$ caused a substantial 34-146\% increase in LDH release compared with that of the vehicle control after $6 \mathrm{~h}$. Similar effects were observed after 24 and $48 \mathrm{~h}$ of exposure to DBP. However, during prolonged exposures to DBP, LDH release increased even with a concentration of $1 \mu \mathrm{M}$ DBP (Fig. 2a).

Neurons were stained with calcein AM to assess the viability of the cells. Living cells display green fluorescence. In the control culture, healthy cells with green fluorescence predominated (Fig. 3). After $24 \mathrm{~h}$ of exposure to $10 \mu \mathrm{M}$ DBP, a reduction in green fluorescence was observed. Staurosporine $(1 \mu \mathrm{M})$ was used as a positive control and caused massive cell death. 

concentrations of DBP $(10,50$, and $100 \mathrm{nM}$ and $1,10,25,50$, and $100 \mu \mathrm{M}$ ) on ROS formation in cultured neocortical neurons after 3, 6, and $24 \mathrm{~h}$ of exposure. Each point represents the mean \pm SEM of four independent experiments, each of which consists of eight replicates per treatment group. $* * * p<0.001$ versus the control cultures
Fig. 1 The effects of increasing

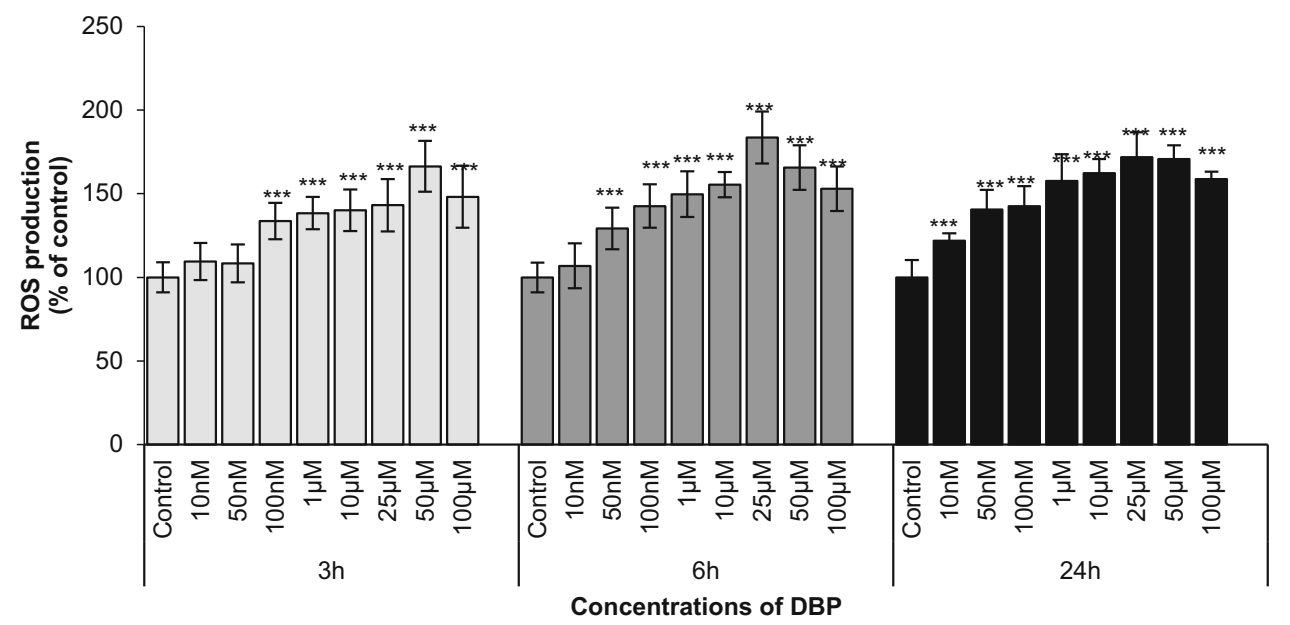

Fig. 2 The effects of increasing concentrations of DBP $(10,50$, and $100 \mathrm{nM}$ and $1,10,25,50$, and $100 \mu \mathrm{M}$ ) on LDH release and caspase- 3 activity in cultured neocortical neurons after 6,24 , and $48 \mathrm{~h}$ of exposure. Each point represents the mean \pm SEM of four independent experiments, each of which consisted of eight replicates per treatment group. $* p<0.05, * * p<0.01$,

$* * * p<0.001$ versus the control cultures

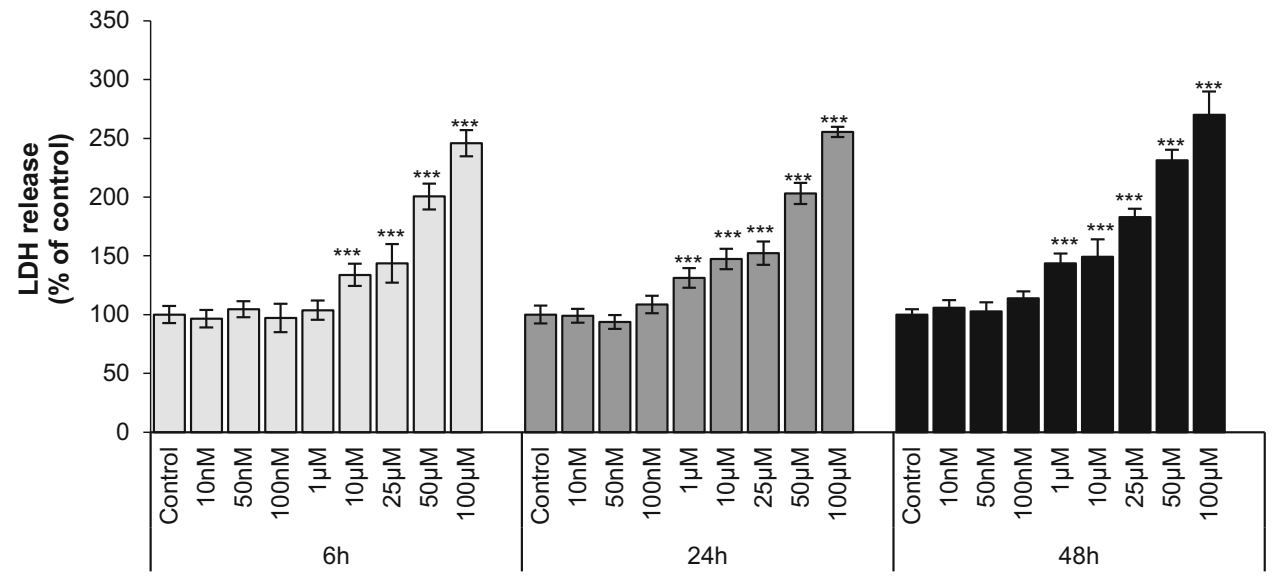

Concentrations of DBP

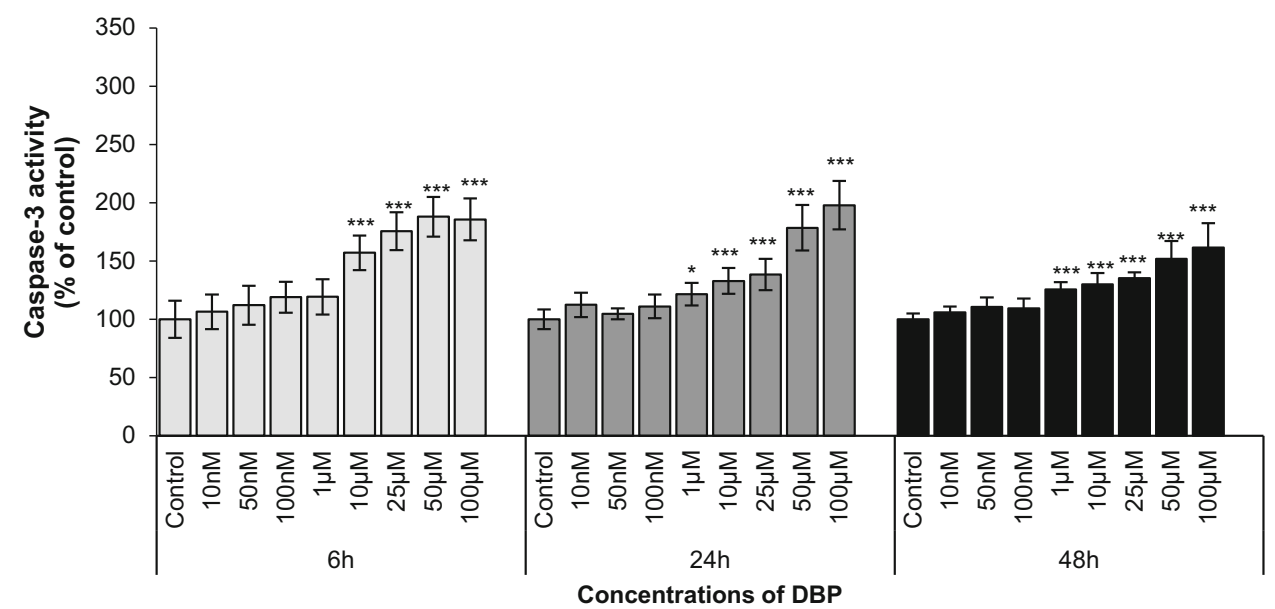

\section{Apoptotic Effect of DBP}

Caspase-3 activity increased significantly following a $6 \mathrm{~h}$ treatment with $10,25,50$, and $100 \mu \mathrm{M}$ DBP. The activity was increased in DBP-treated neuron cultures by 57-88 \% of the activity of the vehicle control (Fig. 2b). Enhanced enzyme activity was also detected after 24 and $48 \mathrm{~h}$ exposures to the phthalate. In these prolonged exposures, DBP was effective even at the lower concentration of $1 \mu \mathrm{M}$.

Neurons were stained with Hoechst 33342 to assess apoptosis. Apoptotic bodies appeared as bright blue fragmented nuclei that showed condensed chromatin, which is characteristic of apoptotic cells. In the control culture, 


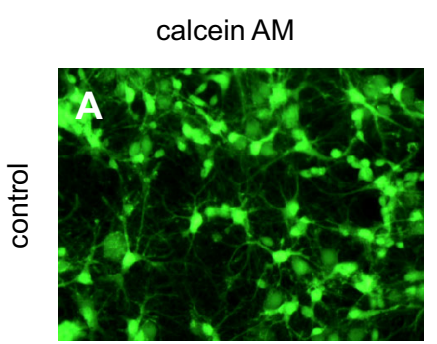

hoechst 33342
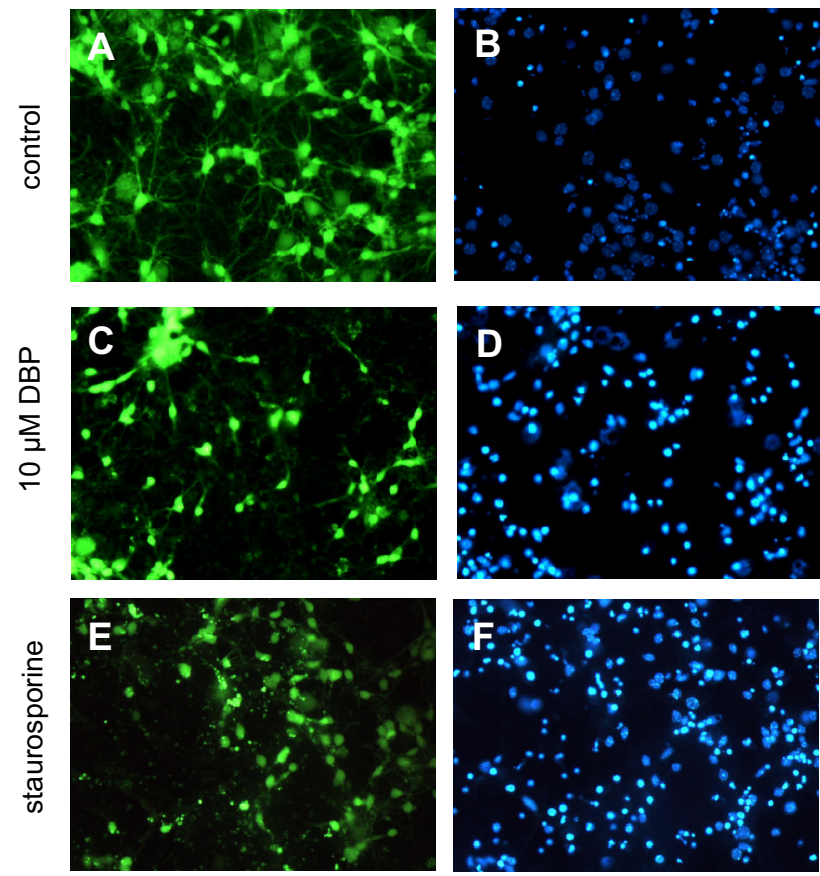

Fig. 3 Effects of DBP on Hoechst 33342 and calcein AM staining in cultures of neocortical neurons examined $24 \mathrm{~h}$ post treatment. a Control cells stained with calcein AM. b Control cells stained with Hoechst 33342. c Cells treated with $10 \mu \mathrm{M}$ DBP and stained with calcein AM. d Cells treated with $10 \mu \mathrm{M}$ DBP and stained with Hoechst 33342. e Cells treated with $1 \mu \mathrm{M}$ staurosporine and stained with calcein AM. f Cells treated with $1 \mu \mathrm{M}$ staurosporine and stained with Hoechst 33342. Cells with bright yellow fluorescence were identified as live cells. Cells with bright, fragmented nuclei containing condensed chromatin were identified as apoptotic cells. Photomicrographs are shown at $\times 200$

healthy cells with intact nuclei were predominant (Fig. 3). The apoptotic bodies were detected after $24 \mathrm{~h}$ of exposure to $10 \mu \mathrm{M}$ of DBP. In addition, staurosporine $(1 \mu \mathrm{M})$ induced apoptotic bodies in neocortical cells.

\section{Effect of DBP on the mRNA Expression of ER $\alpha$, $E R \beta, P P A R \gamma$, and $A h R$}

Neocortical neurons were exposed to DBP $(10 \mu \mathrm{M})$ for $3 \mathrm{~h}$, and a decrease in the mRNA expression of $E R \alpha$ and PPAR $\gamma$ (decreased by 24.39 and $18.86 \%$, respectively) compared to that of the control was observed. However, there was an increase in the expression of $E R \beta$ and $A h R$ compared to that of the control (increased by 92.38 and $30.23 \%$, respectively) (Fig. 4a).

After the cells were exposed to $10 \mu \mathrm{M}$ of DBP for $6 \mathrm{~h}$, we observed decreased mRNA expression of $E R \alpha, E R \beta$, and PPAR $\gamma$ compared to that of the control (decreased by $25.60,34.60$, and $27.17 \%$ respectively) (Fig. $4 b$ ).
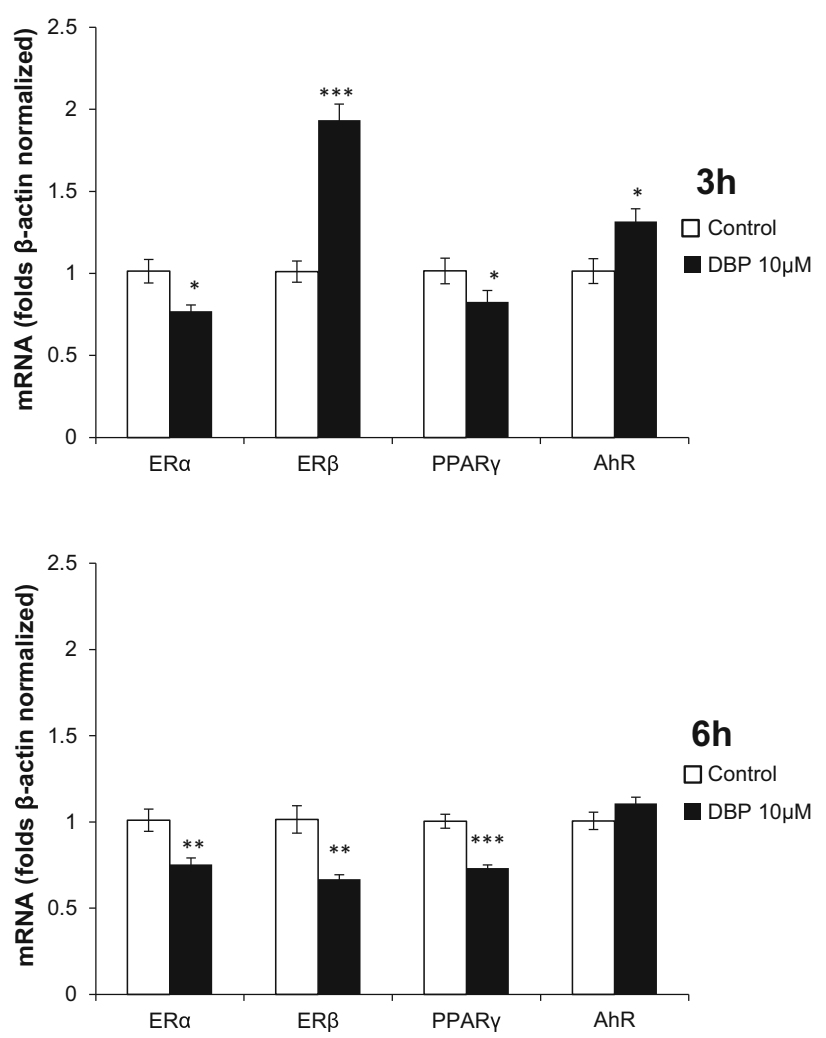

Fig. 4 The effect of $10 \mu \mathrm{M}$ of DBP on mRNA expression of $E R \alpha$, $E R \beta, P P A R \gamma$, and $A h R$ after $3 \mathrm{~h}(\mathbf{a})$ and $6 \mathrm{~h}(\mathbf{b})$ of exposure. mRNA expression was normalized to $\beta$-actin expression. The data are expressed as the mean \pm SEM of four independent experiments, each of which consisted of eight replicates per treatment group. ${ }^{*} p<0.05$, ${ }^{* *} p<0.01, * * * p<0.001$ versus the control

\section{Effect of DBP on Protein Expression of PPAR $\gamma$, AhR, ER $\alpha$, and ER $\beta$}

Immunoblot analyses demonstrated that in neurons treated with $10 \mu \mathrm{M}$ DBP for $6 \mathrm{~h}$, the level of the ER $\alpha$ protein was elevated by $48.57 \%$ compared with that of the control cells. However, after 24 and $48 \mathrm{~h}$ of exposure, expression of this protein decreased by 38.93 and $70.92 \%$, respectively, compared to expression in the control cells (Fig. 5a, b).

A decrease in ER $\beta$ protein expression was observed after 6,24 , and $48 \mathrm{~h}$ of exposure to $10 \mu \mathrm{M}$ of DBP (37.40, 60.60 , and $61.93 \%$ respectively) compared to that of the control cells.

PPAR $\gamma$ protein expression showed a decrease similar to ER $\beta$ expression after 6, 24, and $48 \mathrm{~h}$ of exposure (33.19, 41.17 , and $53.25 \%$ respectively) compared to that of the control cells.

AhR protein expression began to increase after $3 \mathrm{~h}$ by $16.26 \%$ and then significantly decreased after 6,24 , and $48 \mathrm{~h}(37.28,30.60$, and $19.83 \%$ respectively) compared to that of the control cells. 


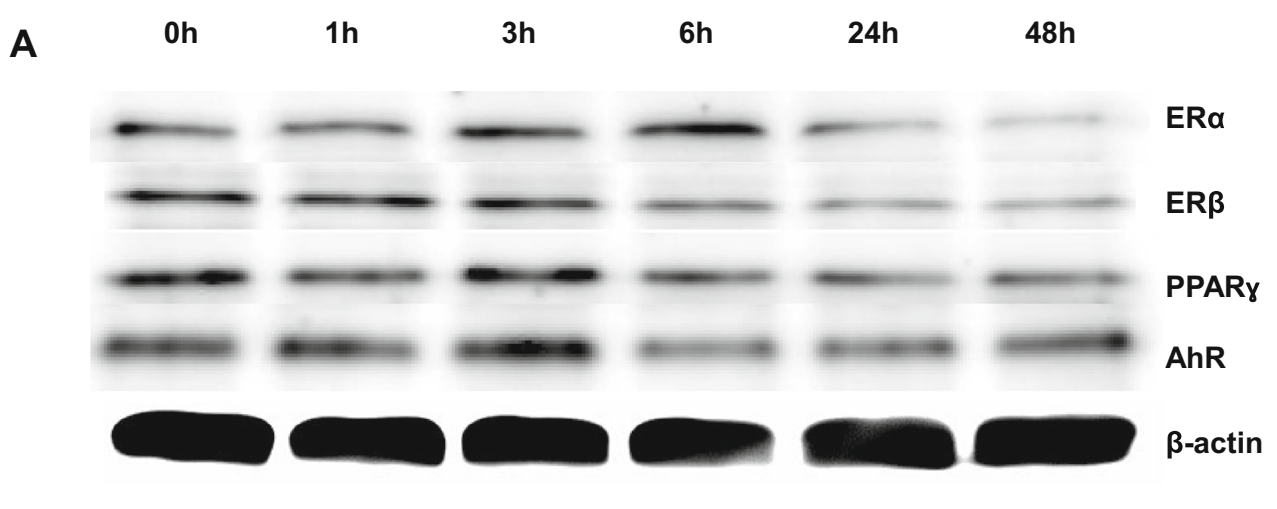

$10 \mu \mathrm{M}$ DBP

B
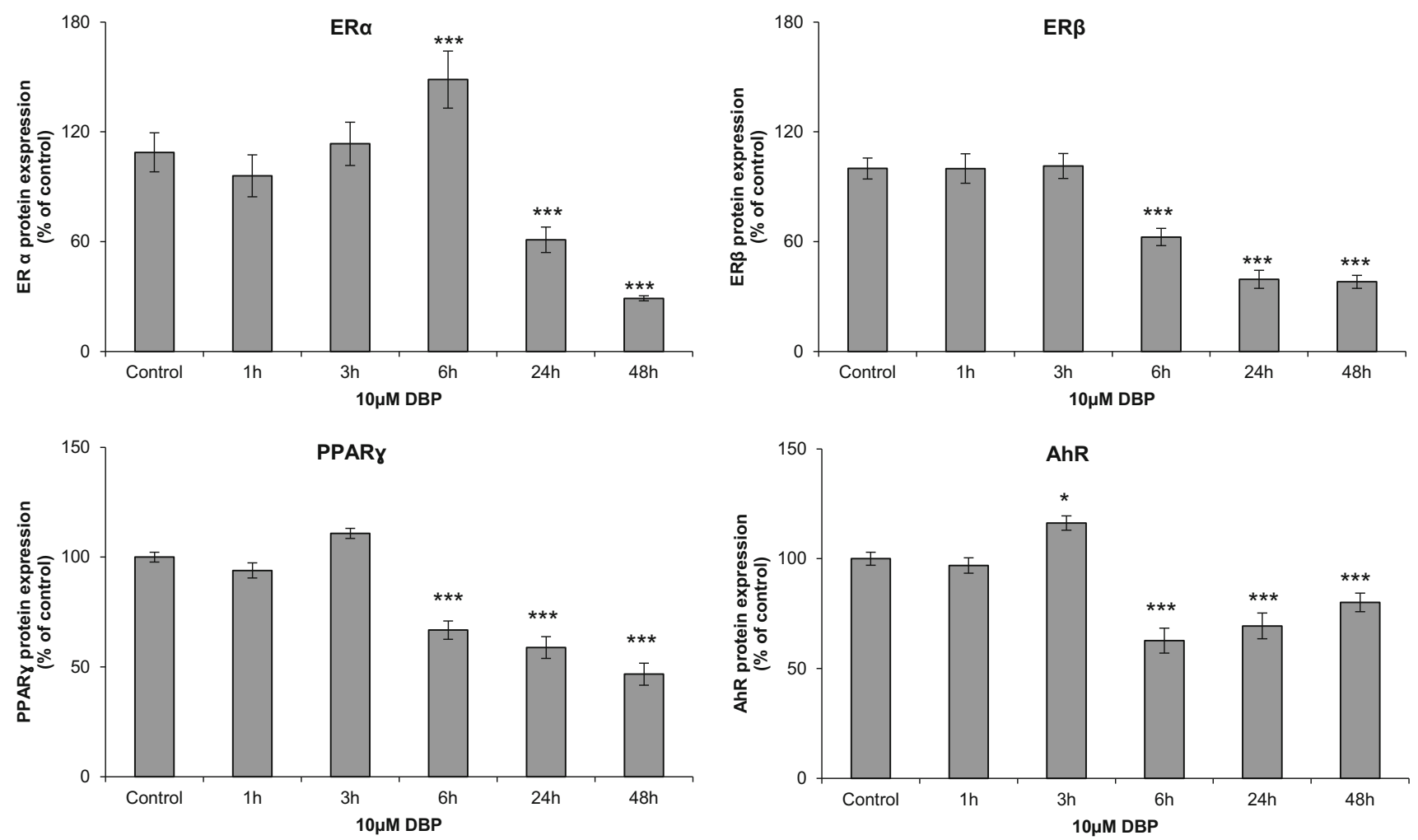

Fig. 5 Representative western blots of ER $\alpha, E R \beta, P P A R \gamma$, and AhR proteins in neocortical neurons treated with $10 \mu \mathrm{M}$ of DBP after 1, 3, 6,24 , and $48 \mathrm{~h}$ (a). Protein bands were quantified by densitometry. The results are shown as the percentage of $\operatorname{ER} \alpha, \operatorname{ER} \beta, \operatorname{PPAR} \gamma$, and AhR proteins relative to the control protein levels. Each column

\section{Neurotoxic and Apoptotic Effects of DBP in siRNA-Transfected Cells}

Neocortical neurons were transfected with scramble siRNA and exposed to DBP $(10 \mu \mathrm{M})$. After $24 \mathrm{~h}$ of exposure, a $49.40 \%$ increase in LDH release compared to that of the vehicle control was observed. The effect of DBP on LDH

represents the mean \pm SEM of three independent experiments (b). The blots were stripped and reprobed with an anti- $\beta$-actin antibody to control for the amounts of protein loaded onto the gel. $* p<0.05$, $* * * p<0.001$ versus the control

release was reversed by transfection of the neurons with ER $\alpha$-, ER $\beta-$, PPAR $\gamma-$, or AhR-specific siRNA (Fig. 6).

Additionally, caspase-3 activity was increased by $30.48 \%$ compared to that of the vehicle control. The effect of DBP on caspase-3 activity was reversed by transfection of the neurons with ER $\alpha$-, ER $\beta$-, or PPAR $\gamma$-specific siRNA. Transfection of the neurons with AhR-specific 

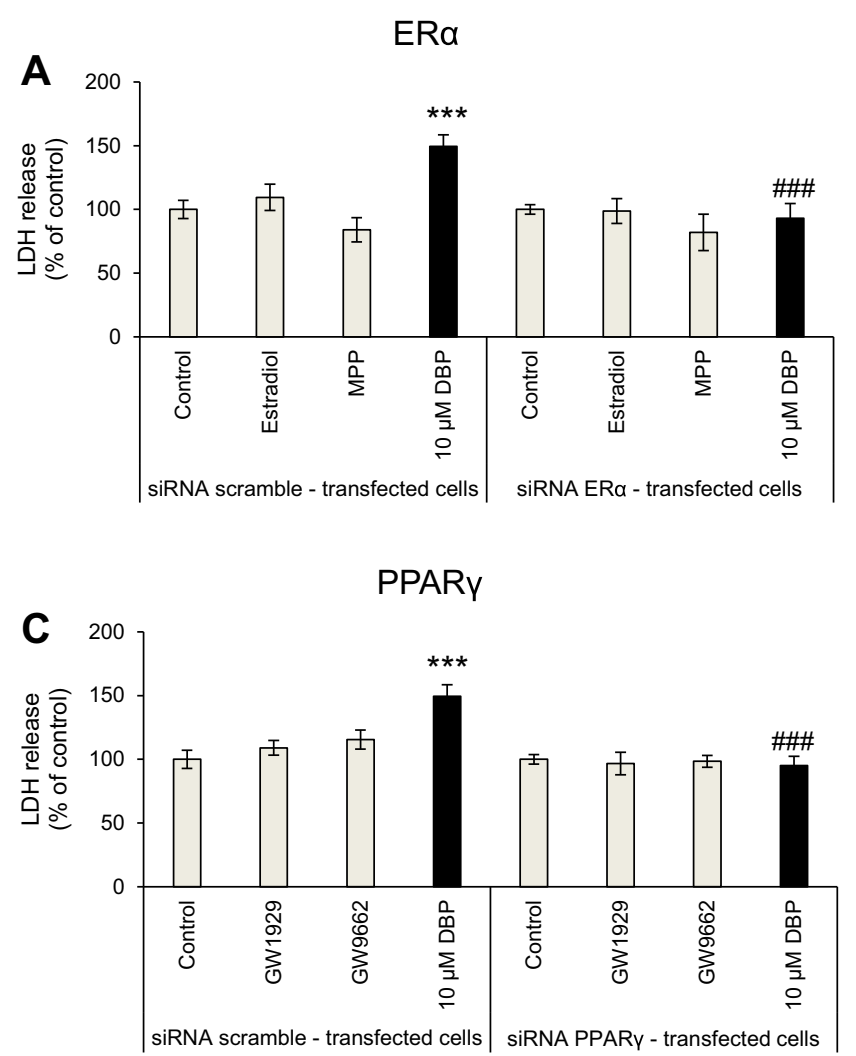

Fig. 6 The effect of $10 \mu \mathrm{M}$ of DBP on LDH release in the negative control siRNA-transfected cells and ER $\alpha$-specific (a), ER $\beta$-specific (b), PPAR $\gamma$-specific (c) and AhR-specific (d) siRNA-transfected cells. Agonists of ER $\alpha$ (estradiol), ER $\beta$ (estradiol), PPAR $\gamma$ $(\mathrm{GW} 1929)$, and AhR ( $\beta \mathrm{NF})$ were tested. Antagonists of $\mathrm{ER} \alpha$

siRNA decreased caspase-3 activity below the control level by $45.52 \%$ (Fig. 7).

The effects of ER (estradiol) or AhR ( $\beta \mathrm{NF}$ ) agonists were reversed by cell transfection with a specific siRNA.

\section{Neurotoxic and Apoptotic Effects of DBP with Co-administration of Receptor Antagonists}

After 24 h of exposure of neocortical neurons to DBP $(10 \mu \mathrm{M})$, a $37.73 \%$ increase in LDH release compared to that of the control vehicle was observed. Co-administration of DBP with an ER $\alpha$ antagonist (MPP), ER $\beta$ antagonist (PHTPP), PPAR $\gamma$ antagonist (GW9662), or AhR antagonist ( $\alpha \mathrm{NF}$ ) potentiated the LDH release compared to that of the vehicle control by $182.68,192.46,162.81$, and $106.33 \%$, respectively (Fig. 8a).

After $24 \mathrm{~h}$ of exposure of neocortical neurons to DBP $(10 \mu \mathrm{M})$, a $25.75 \%$ increase in the caspase-3 activity compared to that of the control vehicle was observed. Coadministration of DBP with an ER $\alpha$ antagonist (MPP), ER $\beta$ antagonist (PHTPP) or PPAR $\gamma$ antagonist (GW9662) increased caspase-3 activity compared to that of the vehicle control by $20.37,47.47$, and $56.30 \%$ respectively (Fig. 8 b).
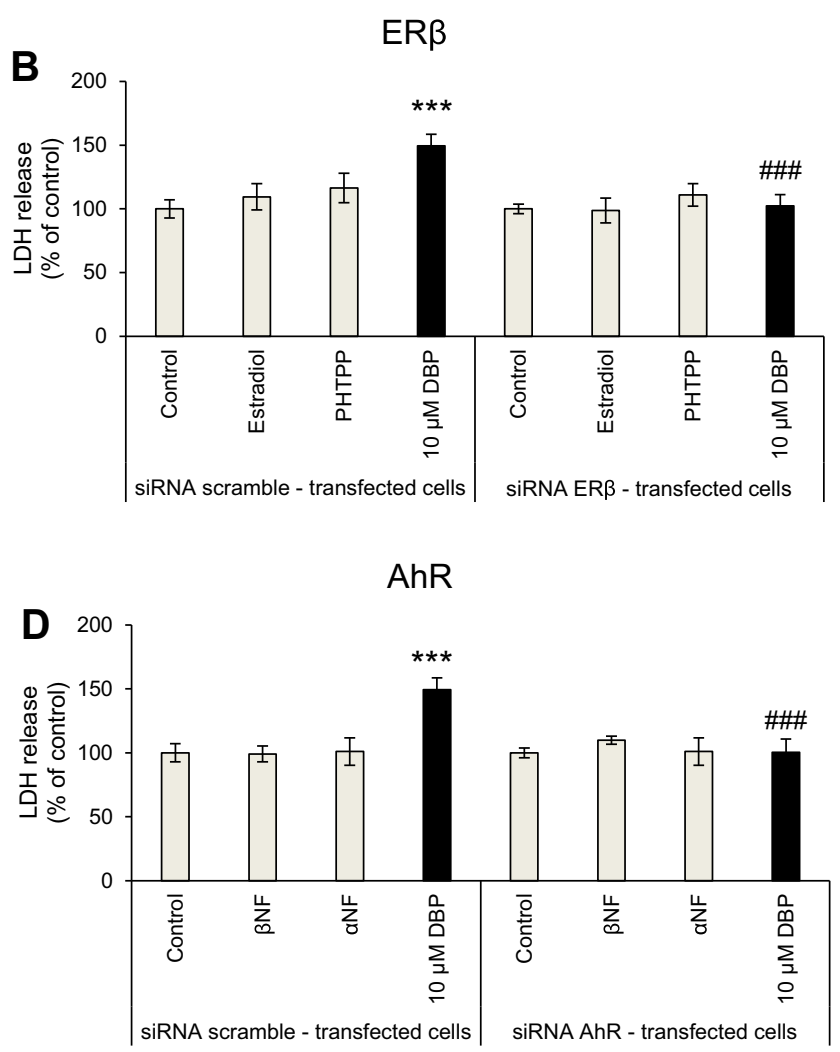

(MPP), ER $\beta$ (PHTPP), PPAR $\gamma$ (GW9662), and AhR ( $\alpha$ NF) were tested. The data are expressed as the mean \pm SEM of four independent experiments, each of which consisted of eight replicates

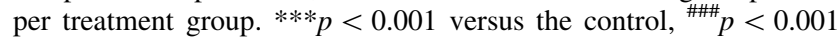
versus the cells transfected with the negative siRNA

\section{Discussion}

This study assessed the neurotoxic and apoptotic effects of DBP in mouse neocortical neurons in primary cultures. DBP stimulated caspase-3 and LDH activities as well as ROS formation in a concentration-(10 $\mathrm{nM}$ to $100 \mu \mathrm{M})$ and time-dependent $(6,24,48 \mathrm{~h})$ manner. Interestingly, DBP induced ROS formation at nanomolar concentrations, while it promoted caspase- 3 activity and LDH release at micromolar concentrations. The biochemical effects of DBP were accompanied by decreased cell viability and increased apoptotic bodies, as determined by Hoechst 33342 and calcein AM staining. Recently, DBP was shown to activate caspase- 3 in the hippocampi of rats that were prenatally exposed to this phthalate ( $\mathrm{Li}$ et al. 2013). In addition, treatment of adult mice with DBP increased ROS formation and caused oxidative damage in brain tissues (Zuo et al. 2014). Moreover, high micromolar concentrations of DBP were found to cause toxicity in rat embryonic midbrain cell cultures and rat mesencephalic neurospheres (Seek Rhee et al. 2002; Ishido and Suzuki 2014). In contrast to our study, $100 \mu \mathrm{M}$ DBP did not cause apoptotic 


\section{ERa}

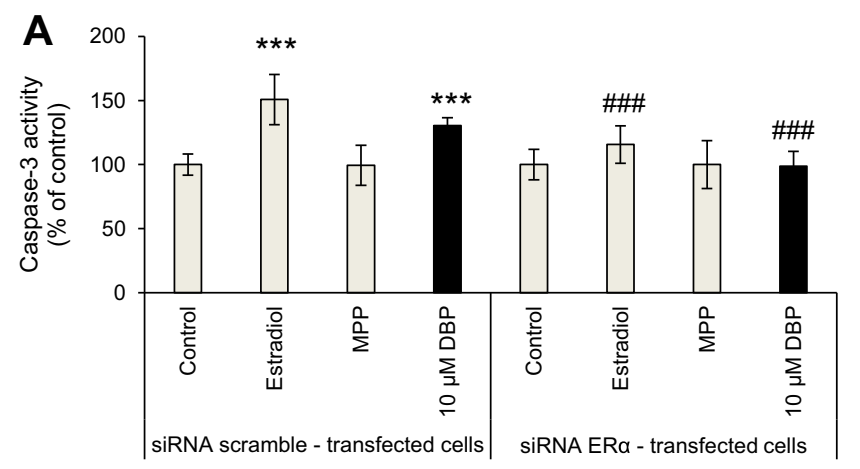

PPARY

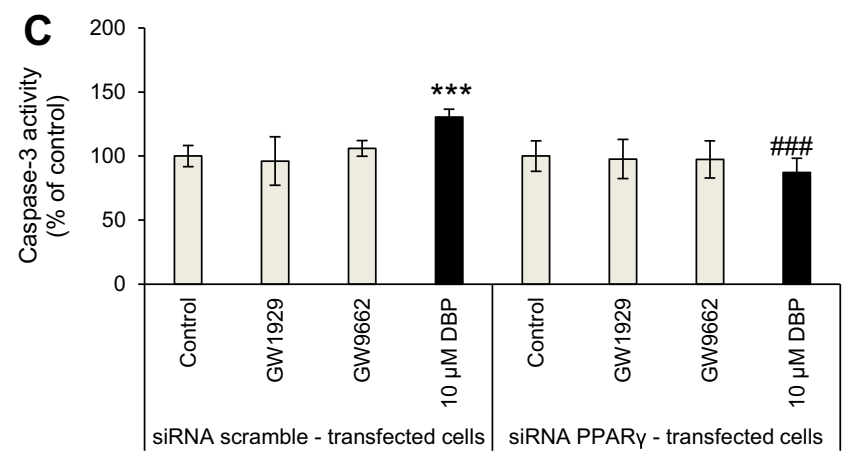

Fig. 7 The effect of $10 \mu \mathrm{M}$ of DBP on caspase-3 activity with negative siRNA-transfected cells and ER $\alpha$-specific (a), ER $\beta$-specific (b), PPAR $\gamma$-specific (c) and AhR-specific (d) siRNA-transfected cells. Agonists of ER $\alpha$ (estradiol), ER $\beta$ (estradiol), PPAR $\gamma$ (GW1929), and AhR ( $\beta N F)$ were tested. Antagonists of ER $\alpha$

effects in the neurospheres as evidenced by TUNEL assays, possibly due to prevalence of DBP-mediated necrosis in these cells. The majority of available studies on phthalateinduced apoptosis and neurotoxicity have focused on the effects of bis(2-ethylhexyl) phthalate (DEHP) and its metabolite mono(2-ethylhexyl) phthalate (MEHP). However, these phthalates have different structures, which may explain their distinct actions in neuronal cells. Similar to the effects of DBP observed in our study, DEHP and MEHP activated caspase- 3 in neuro-2a cells and in neurons derived from mouse embryonic stem cells (Lim et al. 2009; Lin et al. 2011). More recently, Peng showed that exposure of adult mice to diisononyl phthalate increased ROS levels and caspase- 3 activity and expression in brain tissues (Peng 2015).

In addition to the demonstration of apoptotic and neurotoxic effects of DBP, this study verified the involvement of specific nuclear receptors, such as ER $\alpha, \operatorname{ER} \beta, \operatorname{PPAR} \gamma$, and $\mathrm{AhR}$, in the DBP-induced effects. In our study, exposure of cells to DBP reduced ER $\alpha$ and PPAR $\gamma$ mRNA expression levels, which were correlated with decreased protein levels of the receptors. In contrast, treatment with DBP enhanced $A h R$ mRNA expression, which was
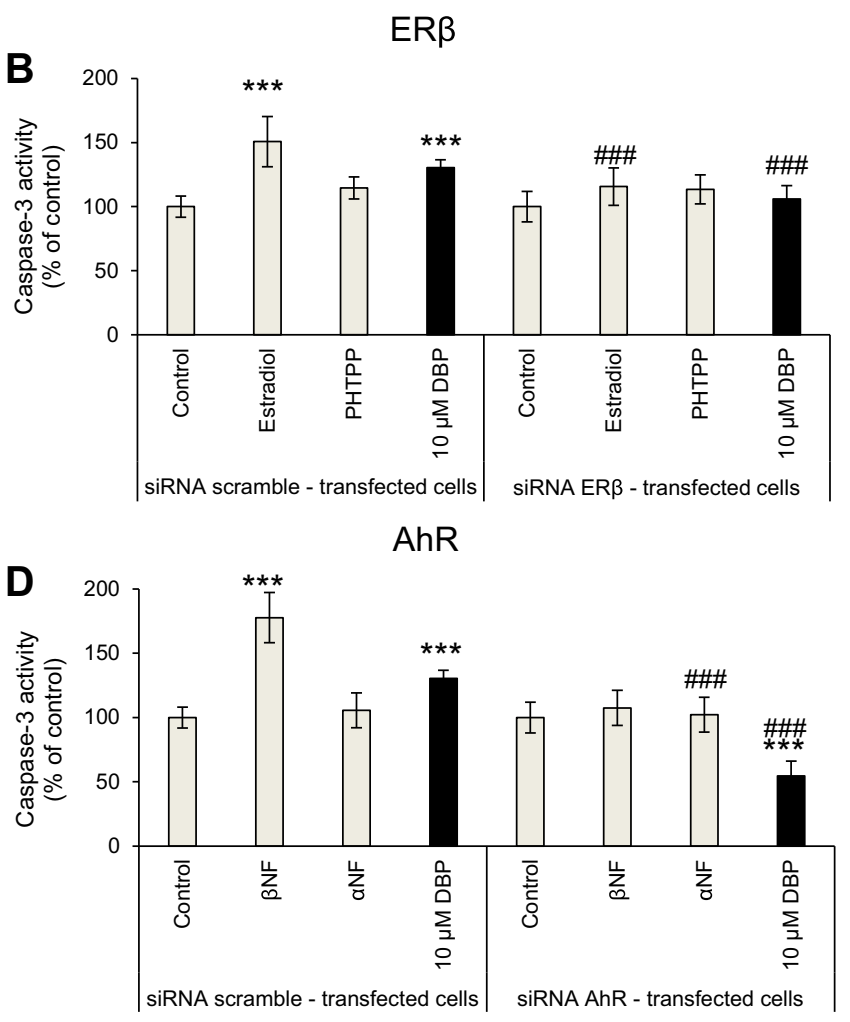

(MPP), ER $\beta$ (PHTPP), PPAR $\gamma$ (GW9662), and AhR ( $\alpha$ NF) were tested. The data are expressed as the mean \pm SEM of four independent experiments, each of which consisted of eight replicates

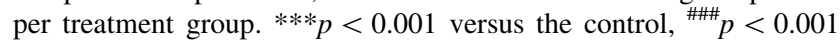
versus the cells transfected with the negative siRNA

reflected by the increased AhR protein level observed after $3 \mathrm{~h}$ of exposure. Interestingly, the DBP-mediated increase in AhR protein was reduced later in the experiment, possibly due to proteasomal degradation of the receptor (Rzemieniec et al. 2015). Chen et al. (2012) showed that AhR protein expression was stimulated by phthalates in human granulosa cells treated with benzyl butyl phthalate (BBP). In our study, a short-term exposure of cells to DBP stimulated $E R \beta$ mRNA expression. However, a long-term exposure of cells to DBP inhibited this expression, which was correlated with reduced protein levels of the receptor. Our findings are consistent with $\mathrm{Li}$ et al. (2014), who showed a down-regulation of ER $\beta$ protein expression in the hippocampi of rats that were prenatally exposed to DBP.

Taking into account the DBP-induced alterations in mRNA and protein levels of nuclear receptors, we suggest that AhR is involved in DBP-induced apoptosis and neurotoxicity, whereas the ERs and PPAR $\gamma$ signaling pathways are impaired by the phthalate. To verify this hypothesis, we employed selective receptor antagonists and agonists as well as specific siRNAs. We demonstrated that treatment of the cells with ER $\alpha, E R \beta$ or PPAR $\gamma$ antagonists stimulated DBP-induced caspase- 3 and LDH activities, 

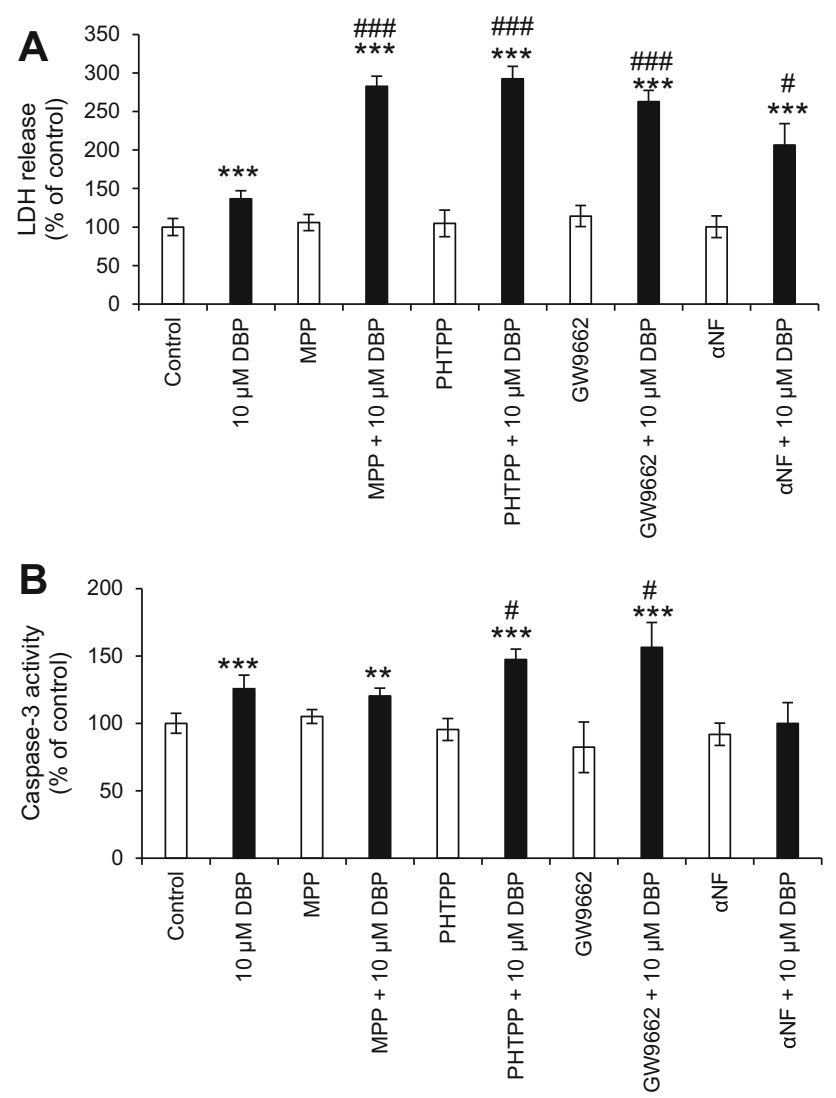

Fig. 8 The effect of $10 \mu \mathrm{M}$ of DBP on LDH release (a) and caspase3 (b) activity after co-administration with antagonists of ER $\alpha$ (MPP), ER $\beta$ (PHTPP), PPAR $\gamma$ (GW9662), and AhR ( $\alpha$ NF) receptors. The data are expressed as the mean \pm SEM of four independent experiments, each of which consisted of eight replicates per treatment group. $* * * p<0.001$ versus the control, ${ }^{\#} p<0.05,{ }^{\# \# \#} p<0.001$; cells treated with $10 \mu \mathrm{M}$ of DBP versus the cells treated with $10 \mu \mathrm{M}$ of DBP with co-administration of a receptor antagonist

which supports our assumption that the effects of DBP are not mediated by ER $\alpha, \mathrm{ER} \beta$, and PPAR $\gamma$. However, this idea was not supported by the experiments using specific siRNAs to silence the receptors. In these experiments, the cells transfected with siRNAs specific for ER $\alpha$ or PPAR $\gamma$ were more resistant to the DBP-induced caspase- 3 and LDH effects, which would suggest that both receptors are involved in DBP-induced apoptosis and neurotoxicity. Recently, crosstalk between estrogen receptors and PPAR $\gamma$ has been identified (Chu et al. 2014). These findings suggest that in the present study, ER $\alpha$ silencing stimulated PPAR $\gamma$ expression, while PPAR $\gamma$ silencing stimulated the expression of ER $\alpha$. Indeed, Ryu et al. (2008) showed that treatment with DBP caused a time- and dose-dependent decrease in the expression of ER $\alpha$ but up-regulated expression of PPAR $\gamma$ in rat testes. Therefore, the reduced effectiveness of DBP observed in the cells with siRNAsilenced ER $\alpha$ could be related to non-specific up-regulation of PPAR $\gamma$. Similarly, the reduced effectiveness of DBP observed in the cells with siRNA-silenced PPAR $\gamma$ would be related to non-specific up-regulation of ER $\alpha$. Both receptors are known to have neuroprotective properties; therefore, their presence in the neuronal cells may attenuate the apoptotic and neurotoxic effects of DBP. Additionally, the effects of DBP in siRNA ER $\beta$-transfected cells were attenuated. We suggest that that these results are due to the ability of DBP to act as a weak ER $\alpha / \beta$ agonist and androgen receptor antagonist, as shown in $\mathrm{CHO}$ cells transfected with human ER $\alpha$ or ER $\beta$ and in $\mathrm{CV}-1$ cells transfected with ER $\alpha$ (Takeuchi et al. 2005; Shen et al. 2009). In addition, ER $\beta$ had neuroprotective effects in primary neocortical, cerebellar, and hippocampal cultures of mouse neurons (Kajta et al. 2013, 2014).

In our study, $\alpha \mathrm{NF}$ failed to antagonize DBP-induced LDH release but it showed tendency to inhibit DBP-induced caspase- 3 activity. It is possibly because $\alpha \mathrm{NF}$ is also a well-documented inhibitor of metabolic reactions that are carried out by the Cyp1a cytochrome family (Bauer et al. 1995). Moreover, we suggest that high concentration of ROS shown in our experiments in response to DBP might have affected expression of AhR-regulated Cyp1a1 that could explain enhanced LDH release in the cells co-treated with DBP and $\alpha$ NF. However, AhR silencing provided evidence that DBP-induced apoptosis and neurotoxicity are mediated by AhR. In the present study, the cells transfected with AhR siRNA were more resistant to the DBP-induced caspase-3 and LDH effects, suggesting the involvement of AhR signaling in DBP-induced effects. Previously, we demonstrated that AhR mediated the apoptotic and neurotoxic effects of DDT and hypoxia (Rzemieniec et al. 2014; Kajta et al. 2014). The only available studies examining the involvement of $\mathrm{AhR}$ in the mechanisms of action of phthalates were performed with DEHP and BBP in human breast cancer and endometrial cells and with a luciferase reporter gene assay (Bredhult et al. 2007; Krüger et al. 2008; Hsieh et al. 2012; Mankidy et al. 2013). In the present study, AhR silencing experiments indicated that DBPinduced apoptosis and neurotoxicity are mediated by AhR. These results are consistent with our data on DBP-induced enhancement of AhR mRNA and protein expression. The experiments performed here support our hypothesis that the effects of DBP in neuronal cells are mediated by AhR.

\section{Conclusion}

Our study examined the neurotoxic and apoptotic effects of DBP in mouse neocortical neurons in primary cultures. DBP stimulated caspase- 3 and LDH activities as well as ROS formation in a concentration- and time-dependent manner. Interestingly, DBP induced ROS formation at nanomolar concentrations, while it activated caspase-3 
activity and LDH release at micromolar concentrations. We demonstrated that the DBP mechanism of action involves ER $\alpha, \operatorname{ER} \beta, \operatorname{PPAR} \gamma$, and AhR. Our study showed that AhR mediates DBP-induced apoptosis and neurotoxicity, whereas the ERs and PPAR $\gamma$ signaling pathways are impaired by the phthalate. However, it is also possible that DBP activates other molecular signaling pathways. Therefore, further studies on the mechanisms underlying the effects of DBP on the nervous system are needed.

Acknowledgments This work was supported by a Grant from the Polish National Science Centre 2012/07/B/NZ4/00238.

Open Access This article is distributed under the terms of the Creative Commons Attribution 4.0 International License (http://crea tivecommons.org/licenses/by/4.0/), which permits unrestricted use, distribution, and reproduction in any medium, provided you give appropriate credit to the original author(s) and the source, provide a link to the Creative Commons license, and indicate if changes were made.

\section{References}

Adibi JJ, Perera FP, Jedrychowski W et al (2003) Prenatal exposures to phthalates among women in New York City and Krakow, Poland. Environ Health Perspect 111:1719-1722. doi:10.1289/ ehp. 6235

Bauer E, Guo Z, Ueng YF et al (1995) Oxidation of benzo[a]pyrene by recombinant human cytochrome P450 enzymes. Chem Res Toxicol 8:136-142

Bradford MM (1976) A rapid and sensitive method for the quantitation of microgram quantities of protein utilizing the principle of protein-dye binding. Anal Biochem 72:248-254

Bredhult C, Bäcklin B-M, Olovsson M (2007) Effects of some endocrine disruptors on the proliferation and viability of human endometrial endothelial cells in vitro. Reprod Toxicol 23:550-559. doi:10.1016/j.reprotox.2007.03.006

Brewer GJ (1997) Isolation and culture of adult rat hippocampal neurons. J Neurosci Methods 71:143-155

Chen HS, Chiang PH, Wang YC et al (2012) Benzyl butyl phthalate induces necrosis by AhR mediation of CYP1B1 expression in human granulosa cells. Reprod Toxicol 33:67-75. doi:10.1016/j. reprotox.2011.11.004

Chu R, van Hasselt A, Vlantis AC et al (2014) The cross-talk between estrogen receptor and peroxisome proliferator-activated receptor gamma in thyroid cancer. Cancer 120:142-153. doi:10.1002/ cncr. 28383

Duty SM, Ackerman RM, Calafat AM, Hauser R (2005) Personal care product use predicts urinary concentrations of some phthalate monoesters. Environ Health Perspect 113:1530-1535. doi:10. 1289/ehp. 8083

Foster PM, Cook MW, Thomas LV et al (1983) Differences in urinary metabolic profile from di- $n$-butyl phthalate-treated rats and hamsters. A possible explanation for species differences in susceptibility to testicular atrophy. Drug Metab Dispos 11:59-61

Fromme H, Küchler T, Otto T et al (2002) Occurrence of phthalates and bisphenol $\mathrm{A}$ and $\mathrm{F}$ in the environment. Water Res 36:1429-1438

Fromme H, Lahrz T, Piloty M et al (2004) Occurrence of phthalates and musk fragrances in indoor air and dust from apartments and kindergartens in Berlin (Germany). Indoor Air 14:188-195. doi:10.1111/j.1600-0668.2004.00223.x
Fujii M, Shinohara N, Lim A et al (2003) A study on emission of phthalate esters from plastic materials using a passive flux sampler. Atmos Environ 37:5495-5504. doi:10.1016/j.atmosenv. 2003.09.026

Gomes A, Fernandes E, Lima JLFC (2005) Fluorescence probes used for detection of reactive oxygen species. J Biochem Biophys Methods 65:45-80. doi:10.1016/j.jbbm.2005.10.003

Heudorf U, Mersch-Sundermann V, Angerer J (2007) Phthalates: toxicology and exposure. Int $\mathrm{J}$ Hyg Environ Health 210:623-634. doi:10.1016/j.ijheh.2007.07.011

Högberg J, Hanberg A, Berglund M et al (2008) Phthalate diesters and their metabolites in human breast milk, blood or serum, and urine as biomarkers of exposure in vulnerable populations. Environ Health Perspect 116:334-339. doi:10.1289/ehp.10788

Hsieh TH, Tsai CF, Hsu CY et al (2012) Phthalates induce proliferation and invasiveness of estrogen receptor-negative breast cancer through the AhR/HDAC6/c-Myc signaling pathway. FASEB J 26:778-787. doi:10.1096/fj.11-191742

Huang Y, Li J, Garcia JM et al (2014) Phthalate levels in cord blood are associated with preterm delivery and fetal growth parameters in Chinese women. PLoS One 9:e87430. doi:10.1371/journal. pone. 0087430

Ishido M, Suzuki J (2014) Classification of phthalates based on an in vitro neurosphere assay using rat mesencephalic neural stem cells. J Toxicol Sci 39:25-32. doi:10.2131/jts.39.25

Kajta M, Lasoń W, Kupiec T (2004) Effects of estrone on $N$-methylD-aspartic acid- and staurosporine-induced changes in caspase-3like protease activity and lactate dehydrogenase-release: timeand tissue-dependent effects in neuronal primary cultures. Neuroscience 123:515-526

Kajta M, Trotter A, Lasoń W, Beyer C (2005) Effect of NMDA on staurosporine-induced activation of caspase- 3 and LDH release in mouse neocortical and hippocampal cells. Dev Brain Res 160:40-52. doi:10.1016/j.devbrainres.2005.08.002

Kajta M, Wójtowicz AK, Maćkowiak M, Lasoń W (2009) Aryl hydrocarbon receptor-mediated apoptosis of neuronal cells: a possible interaction with estrogen receptor signaling. Neuroscience 158:811-822. doi:10.1016/j.neuroscience.2008.10.045

Kajta M, Rzemieniec J, Litwa E et al (2013) The key involvement of estrogen receptor $\beta$ and G-protein-coupled receptor 30 in the neuroprotective action of daidzein. Neuroscience 238:345-360. doi:10.1016/j.neuroscience.2013.02.005

Kajta M, Litwa E, Rzemieniec J et al (2014) Isomer-nonspecific action of dichlorodiphenyltrichloroethane on aryl hydrocarbon receptor and G-protein-coupled receptor 30 intracellular signaling in apoptotic neuronal cells. Mol Cell Endocrinol 392:90-105. doi:10.1016/j.mce.2014.05.008

Kasuya M (1974) Toxicity of phthalate esters to nervous tissue in culture. Bull Environ Contam Toxicol 12:167-172. doi:10.1007/ BF01684955

Kaun-Yu L, Fu-Wei T, Chia-Jung W, Pei-Shan L (2004) Suppression by phthalates of the calcium signaling of human nicotinic acetylcholine receptors in human neuroblastoma SH-SY5Y cells. Toxicology 200:113-121. doi:10.1016/j.tox.2004.03.018

Kavlock R, Barr D, Boekelheide K et al (2006) NTP-CERHR expert panel update on the reproductive and developmental toxicity of di(2-ethylhexyl) phthalate. Reprod Toxicol 22:291-399

Kawano M (1980) Toxicological studies on phthalate esters. 2. Metabolism, accumulation and excretion of phthalate esters in rats (author's transl). Nihon Eiseigaku Zasshi 35:693-701

Koh JY, Choi DW (1987) Quantitative determination of glutamate mediated cortical neuronal injury in cell culture by lactate dehydrogenase efflux assay. J Neurosci Methods 20:83-90. doi:10.1016/0165-0270(87)90041-0

Krüger T, Long M, Bonefeld-Jørgensen EC (2008) Plastic components affect the activation of the aryl hydrocarbon and the 
androgen receptor. Toxicology 246:112-123. doi:10.1016/j.tox. 2007.12.028

Li Y, Zhuang M, Li T, Shi N (2009) Neurobehavioral toxicity study of dibutyl phthalate on rats following in utero and lactational exposure. J Appl Toxicol 29:603-611. doi:10.1002/jat.1447

Li X-J, Jiang L, Chen L et al (2013) Neurotoxicity of dibutyl phthalate in brain development following perinatal exposure: a study in rats. Environ Toxicol Pharmacol 36:392-402. doi:10. 1016/j.etap.2013.05.001

Li X, Jiang L, Cheng L, Chen H (2014) Dibutyl phthalate-induced neurotoxicity in the brain of immature and mature rat offspring. Brain Dev 36:653-660. doi:10.1016/j.braindev.2013.09.002

Lien Y-J, Ku H-Y, Su P-H et al (2014) Prenatal exposure to phthalate esters and behavioral syndromes in children at eight years of age: taiwan maternal and infant cohort study. Environ Health Perspect. doi:10.1289/ehp.1307154

Lim CK, Kim S-K, Ko DS et al (2009) Differential cytotoxic effects of mono-(2-ethylhexyl) phthalate on blastomere-derived embryonic stem cells and differentiating neurons. Toxicology 264:145-154. doi:10.1016/j.tox.2009.08.015

Lin C-H, Chen T-J, Chen S-S et al (2011) Activation of Trim17 by PPAR $\gamma$ is involved in di(2-ethylhexyl) phthalate (DEHP)induced apoptosis on neuro-2a cells. Toxicol Lett 206:245-251. doi:10.1016/j.toxlet.2011.08.002

Mankidy R, Wiseman S, Ma H, Giesy JP (2013) Biological impact of phthalates. Toxicol Lett 217:50-58. doi:10.1016/j.toxlet.2012. 11.025

Nicholson DW, Ali A, Thornberry NA et al (1995) Identification and inhibition of the ICE/CED-3 protease necessary for mammalian apoptosis. Nature 376:37-43. doi:10.1038/376037a0

Otake T, Yoshinaga J, Yanagisawa Y (2004) Exposure to phthalate esters from indoor environment. J Expo Anal Environ Epidemiol 14:524-528. doi:10.1038/sj.jea.7500352

Peng L (2015) Mice brain tissue injury induced by diisononyl phthalate exposure and the protective application of vitamin $\mathrm{E}$. J Biochem Mol Toxicol 29:311-320. doi:10.1002/jbt.21700

Rowland IR, Cottrell RC, Phillips JC (1977) Hydrolysis of phthalate esters by the gastro-intestinal contents of the rat. Food Cosmet Toxicol 15:17-21

Rudel RA, Camann DE, Spengler JD et al (2003) Phthalates, alkylphenols, pesticides, polybrominated diphenyl ethers, and other endocrine-disrupting compounds in indoor air and dust. Environ Sci Technol 37:4543-4553

Ryu JY, Lee E, Kim TH et al (2008) Time-response effects of testicular gene expression profiles in Sprague-Dawley male rats treated with di(n-butyl) phthalate. J Toxicol Environ Health 71:1542-1549. doi:10.1080/15287390802391992

Rzemieniec J, Litwa E, Wnuk A et al (2014) Neuroprotective action of raloxifene against hypoxia-induced damage in mouse hippocampal cells depends on ER $\alpha$ but not ER $\beta$ or GPR30 signalling. J Steroid Biochem Mol Biol 146:26-37. doi:10. 1016/j.jsbmb.2014.05.005

Rzemieniec J, Litwa E, Wnuk A et al (2015) Selective aryl hydrocarbon receptor modulator 3,3'-diindolylmethane impairs $\mathrm{AhR}$ and
ARNT signaling and protects mouse neuronal cells against hypoxia. Mol Neurobiol. doi:10.1007/s12035-015-9471-0

Saillenfait AM, Payan JP, Fabry JP et al (1998) Assessment of the developmental toxicity, metabolism, and placental transfer of din-butyl phthalate administered to pregnant rats. Toxicol Sci 45:212-224. doi:10.1006/toxs.1998.2518

Seek Rhee G, Hee Kim S, Sun Kim S et al (2002) Comparison of embryotoxicity of ESBO and phthalate esters using an in vitro battery system. Toxicol In Vitr 16:443-448. doi:10.1016/S08872333(02)00026-7

Shea KM (2003) Pediatric exposure and potential toxicity of phthalate plasticizers. Pediatrics 111:1467-1474

Shen O, Du G, Sun H et al (2009) Comparison of in vitro hormone activities of selected phthalates using reporter gene assays. Toxicol Lett 191:9-14. doi:10.1016/j.toxlet.2009.07.019

Stales CA, Peterson DR, Parkerton TF, Adams WJ (1997) The environmental fate of phthalate esters: a literature review. Chemosphere 35:667-749. doi:10.1016/S0045-6535(97)00195-1

Szychowski KA, Wójtowicz AK (2016) TBBPA causes neurotoxic and the apoptotic responses in cultured mouse hippocampal neurons in vitro. Pharmacol Reports 68:20-26. doi:10.1016/j. pharep.2015.06.005

Szychowski KA, Sitarz AM, Wojtowicz AK (2015) Triclosan induces Fas receptor-dependent apoptosis in mouse neocortical neurons in vitro. Neuroscience 284:192-201. doi:10.1016/j.neuroscience. 2014.10.001

Takeuchi S, Iida M, Kobayashi S et al (2005) Differential effects of phthalate esters on transcriptional activities via human estrogen receptors $\alpha$ and $\beta$, and androgen receptor. Toxicology 210:223-233. doi:10.1016/j.tox.2005.02.002

Tanaka A, Matsumoto A, Yamaha T (1978) Biochemical studies on phthalic esters. III. Metabolism of dibutyl phthalate (DBP) in animals. Toxicology 9:109-123

Tseng I-L, Yang Y-F, Yu C-W et al (2013) Phthalates induce neurotoxicity affecting locomotor and thermotactic behaviors and AFD neurons through oxidative stress in caenorhabditis elegans. PLoS One 8:e82657. doi:10.1371/journal.pone.0082657

Wellejus A, Dalgaard M, Loft S (2002) Oxidative DNA damage in male Wistar rats exposed to di-n-butyl phthalate. J Toxicol Environ Health A 65:813-824. doi:10.1080/00984100290071126

Williams DT, Blanchfield BJ (1975) The retention, distribution, excretion, and metabolism of dibutyl phthalate-7-14 $\mathrm{C}$ in the rat. J Agric Food Chem 23:854-858

Xu H, Shao X, Zhang Z et al (2013) Effects of di-n-butyl phthalate and diethyl phthalate on acetylcholinesterase activity and neurotoxicity related gene expression in embryonic zebrafish. Bull Environ Contam Toxicol 91:635-639. doi:10.1007/s00128013-1101-9

Zuo HX, Li JQ, Han B et al (2014) Di-(n-butyl)-phthalate-induced oxidative stress and depression-like behavior in mice with or without ovalbumin immunization. Biomed Environ Sci 27:268-280. doi:10.3967/bes2014.001 